\title{
Dimensional Stability and Water Absorption of Spruce Wood (Picea Abies Karst.) Impregnated and Coated with Polyurethane and Acrylic Coatings
}

\section{Dimenzijska stabilnost i apsorpcija vode smrekovine (Picea abies Karst.) impregnirane i premazane poliuretanskim i akrilnim premazom}

\author{
Original scientific paper $\bullet$ Izvorni znanstveni rad \\ Received-prispjelo: 30. 6. 2017. \\ Accepted-prihvaćeno: 23. 5. 2018. \\ UDK: $630 * 812.22 ; 630 * 812.23 ; 630 * 841 ; 674.032 .13$ \\ doi:10.5552/drind.2018.1740
}

\begin{abstract}
Impregnating materials may affect the stabilization of wood dimensions in two ways: blocking of free water movement paths and chemical connection with hydroxyl groups of wood. The degree of modification depends on the applied material, its penetration and fixation to the wood. The paper investigates the impact of impregnation and coating with polyurethane and acrylic coatings of spruce wood (Picea abies Karst.) on absorption of water and dimensional stability of wood (anti-shrinking efficiency) after being immersed in water for a specific time. Impregnated spruce wood absorbs two times less water than untreated wood and it is dimensionally more stable than coated spruce wood. The water absorption of coated spruce wood is low, but it is not dimensionally stable.
\end{abstract}

Keywords: impregnation, coatings, spruce wood, anti-shrinking efficiency

SAŽETAK・Impregnacijski materijali utječu na dimenzijsku stabilnost drva na dva načina: blokiranjem putova za slobodno kretanje vode i uspostavom kemijskih veza s hidroksilnim skupinama drvne tvari. Stupanj modifikacije ovisi o impregnacijskom sredstvu te o njegovoj penetraciji i fiksaciji u drvu. U radu je prikazano istraživanje utjecaja impregnacije drva i premazivanja smrekovine (Picea abies Karst.) poliuretanskim i akrilnim premazima na apsorpciju vode $i$ dimenzijsku stabilnost drva (Anti shrinking efficiency) nakon određenog vremena natapanja $u$ vodi. Impregnirana je smrekovina upila dva puta manje vode od neimpregniranog drva i dimenzijski je stabilnija od smrekovine zaštićene premazivanjem. Premazana smrekovina pokazala je sposobnost vrlo male apsorpcije vode, ali nije ostala dimenzionalno stabilna.

Ključne riječi: impregnacija, premazi, smrekovina, poboljšanje dimenzijske stabilnosti drva

\footnotetext{
${ }^{1}$ Authors are full time professor and laboratory technician at Ss. Cyril and Methodius University in Skopje, Faculty of Design and Technologies of Furniture and Interior - Skopje, Republic of Macedonia.

Autori su profesor i laboratorijski tehničar Sveučilišta Sveti Ćiril i Metod u Skoplju, Fakultet dizajna i tehnologije namještaja i interijera, Skoplje, Republika Makedonija.
} 


\section{INTRODUCTION}

\section{UVOD}

Wood products in outdoor use are exposed to both short-term and long-term water damage. The dimension stability of wood depends on its properties, processing technology, surface treatment and used materials. In a humid environment, the wood absorbs water until the moisture equilibrium is reached. At the same time, wood dimensions are changed, which has a negative impact on wood products. Therefore, there is a need for surface treatments that would protect the products and keep their dimensional stability.

Coating is a traditional method of surface treatment of wood and it is applied to provide its dimensional stabilization (Rowell, 1981). It is known that the wood coating film is relatively porous, thereby absorbs water, causing resizing of the wood. This method is not sufficiently effective and transparent coatings are not recommended as a long-term protection of wood especially wood used in the exterior, where the coatings should be renewed periodically (TRADA, 1984). A possible solution to this problem is the wood modification method (Jirouš-Rajković et al., 2007), which changes the natural properties of wood with the aim of improving its properties and extending the duration of its use. A type of wood modification is the impregnation with resins (Hill, 2006).

Impregnation is a capillary saturation of wood cavities with implanted viscous materials aimed at reducing its porosity. There are different types of wood modification: filling the lumens - lumen modification, penetrating in the cell wall - cell modification, and chemical reaction between the implanting material and the cellulose hydroxyl groups - chemical modification (Homan, 2004). Also the implanting materials can cause dimensional stabilization in two ways: by blocking the water paths in the wood and disabling the cellulose hydroxyl groups to connect with the water. The degree of modification depends on the applied material penetration and fixation in the wood (Archer and Lebow, 2006).

A possible solution that may address the problem of wood dimensional instability is the impregnation with coatings as a wood surface treatment. Using the vacuum method to implant these materials in the wood may result in the obstruction of the water movement paths or in a chemical modification of the cellulose material, which will increase the wood dimensional stability. Most commonly used wood coatings are those based on polyurethane and acryl resins (Bulian and Graystone, 2009). Both resins have the ability to react with the wood, forming covalent bonds with the cellulose molecule (Rowell and Banks, 1985), which results in a modification of wood surfaces.

The purpose of this investigation is to determine the influence of wood impregnation with polyurethane and acrylic coatings on water absorption and dimensional stability, after several days of immersion in water. It also aims to compare these properties between the untreated wood surfaces, impregnated wood sur- faces and wood surfaces coated with those two coatings.

Understanding the complexity of this problem, the investigation should contribute to improving the dimensional stability of the wood used for making interior and exterior wood products.

\section{MATERIALS AND METHODS}

2. MATERIJALI I METODE

2.1 Preparation of test pieces

2.1. Izrada ispitnih uzoraka

Test pieces were made of spruce wood (Picea abies Karst.) in dimensions 20x20x30 mm. The selected wood was without visible flaws, average growth in radial direction to eight annual rings of $10 \mathrm{~mm}$. Test pieces were conditioned to equilibrium moisture content of the wood in accordance with ISO 554.

The moisture content and wood density were determined according to ISO 3130 and ISO 3131 standards. The average value of moisture content was $W=$ $12 \%$, the average value of density in absolutely dry condition was $\rho_{\mathrm{o}}=0.45 \mathrm{~g} / \mathrm{cm}^{3}$. Two impregnated groups and two coated groups with 32 test pieces were treated for each type of coating, as well as a control group of untreated pieces.

\subsection{Coating properties
2.2. Svojstva premaza}

The coatings were based on polyurethane and acrylic resins, standard products from the range of a reputable manufacturer (ICA LP152P and ICA LAC367). The preparation of the coatings was carried out according to the instructions given by the manufacturer; they were not additionally diluted. The viscosity was determined according to ISO 2431 standard, and the dry residue percentage according to ISO 1515 standard. The polyurethane coating viscosity was $v_{\mathrm{pu}}=15$ " $\mathrm{F} 4 / 20{ }^{\circ} \mathrm{C}$ and the acrylic coating viscosity was $v_{\text {ak }}=27$ " F4/ $20^{\circ} \mathrm{C}$. During the process, the viscosity was not changed. The dry residue of polyurethane coating was $\mathrm{N} . \mathrm{V}_{\mathrm{pu}}=49.3 \%$, and the one of acrylic coating was $\mathrm{N} . \mathrm{V}_{\mathrm{ak}}^{\mathrm{pu}}=54 \%$. Although the amount of the dry residue of the acrylic coating was slightly higher, the difference of $4.7 \%$ was statistically negligible.

\subsection{Impregnation procedure}

\subsection{Postupak impregnacije}

Wood impregnation was performed according to "Double Vacuum Process" procedure (Videlov, 1980; Richardson, 2003). This treatment is applied to impermeable wood species, where the impregnation pressure has a minor impact on the penetration and retention of wood materials, while the increased time of action has a more significant impact (Richardson, 2003). The wood test pieces were completely immersed in the coating solution. The final operation of the vacuum procedure (Figure 1 point 6 and 7) was to remove the impregnating solution from the autoclave, in order to prevent the formation of the film on the wood surface. The ratio of pressure and time of the operation is shown in Figure 1. 


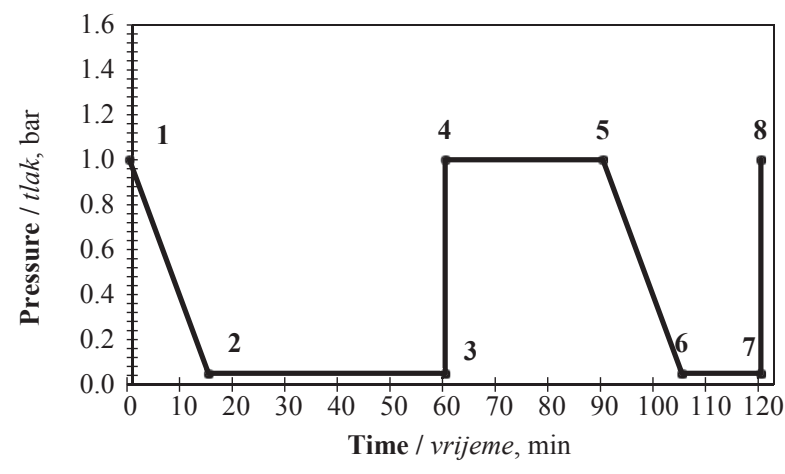

Figure 1 Mode treatment of samples

Slika 1. Postupak tretmana uzoraka

After the treatment, the poly-addition process was carried out until reaching the constant weight, under conditions of ISO 554 standard.

Following the impregnation and surface coating, the test pieces were immersed in water for a period of seven days. The dimensional stability was investigated throughout the mass increase as weight percentage gain, water absorption and anti- shrinking efficiency.

The weight percentage gain - WPG is defined by the formula (Hill, 2006):

$$
W P G=\frac{m_{\mathrm{m}}-m_{\mathrm{u}}}{m_{\mathrm{u}}} \cdot 100
$$

$m_{\mathrm{m}}$ - mass of treated sample / masa tretiranog uzorka $(\mathrm{g})$ $m_{\mathrm{u}}$ - mass of sample before treatment / masa uzorka prije tretmana $(\mathrm{g})$

Water absorption - $W_{\mathrm{a}}$ is expressed by the percentage of humidity of the sample before and after immersion, according to the formula:

$$
W_{\mathrm{a}}=\frac{m_{2}-m_{1}}{m_{1}} \cdot 100
$$

$m_{1}$ - mass of sample before immersion / masa uzorka prije uranjanja $u$ vodu $(\mathrm{g})$

$m_{2}$ - mass of sample with absorbed water / masa uzorka s apsorbiranom vodom (g)
The dimensional stability is expressed as antishrinking efficiency - ASE is defined by the formula (Stamm, 1964):

$$
A S E=\frac{\beta_{v u}-\beta_{v m}}{\beta_{v u}} \cdot 100
$$

$\beta_{\mathrm{vu}}-$ volume swelling of control test piece / volumno bubrenje kontrolnoga ispitnog uzorka (\%)

$\beta_{\mathrm{vm}}$ - volume swelling of treated test piece / volumno bubrenje tretiranoga ispitnog uzorka $(\%)$

Statistical data processing - checking the differences between two related values; significance for statistical data sets with over 30 measurements is determined by:

$$
\mathrm{T}=\frac{\bar{x}_{1}-\bar{x}_{2}}{\sqrt{\frac{\sigma_{1}^{2}}{n_{1}}+\frac{\sigma_{2}^{2}}{n_{2}}}}
$$

The level of the test significance $\alpha=0.01$, or the degree of reliability of $99 \%$, whereby the critical values are outside of the threshold of \pm 2 .

\section{RESULTS AND DISCUSSION}

3. REZULTATI I RASPRAVA

\subsection{Weight percentage gain - WPG}

3.1. Postotno povećanje mase drva

The average value of the weight percentage gain of wood pieces impregnated with polyurethane coating is $20.3 \%$ higher than the average value of wood pieces impregnated with acrylic coating, but according to the factor of significance $(T=1.57)$, the weight increase is not significant. The average WPG values of the samples are shown in Figure 2. Also, the average value of the weight percentage gain of wood coated with acrylic is $12.5 \%$ higher than the weight percentage gain of wood coated with a polyurethane coating, but this difference is not statistically significant $(T=1.5)$.

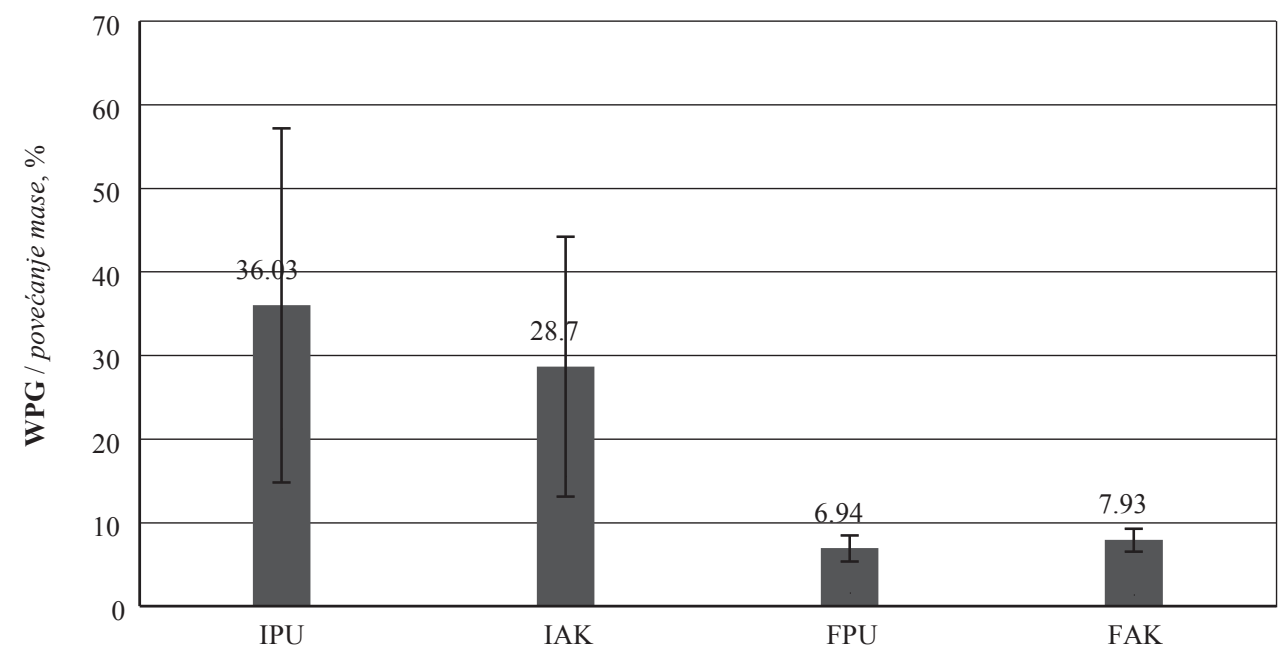

Figure 2 Weight percentage gain of test pieces (IPU - samples impregnated with polyurethane, IAK - samples impregnated with acrylic, FPU - samples coated with polyurethane, FAK - samples coated with acrylic)

Slika 2. Postotno povećanje mase ispitnih uzoraka (IPU - uzorci impregnirani poliuretanom, IAK - uzorci impregnirani akrilom, FPU - uzorci s poliuretanskim premazom, FAK - uzorcimi s akrilnim premazom) 
The differences in WPG of the impregnated wood are followed by high coefficients of variation. This is confirmed by the fact that spruce wood is not permeable and it is processed with difficulties due to impregnation (Militz, 1993; Mamonova, 2000). It is the result of closed pore structure of spruce wood, created during the wood drying process. It is also the result of low permeability of the cell lumens (Gindl et $a l ., 2006$ ), and this is the reason for low penetration of the impregnating materials in the wood.

\subsection{Water absorption}

\subsection{Upijanje vode}

Water absorption was gradually increased in all tested groups during a seven-day immersion. By the fourth day it was intense, and with low dynamics it increased until the last day. Water absorption is shown in Figure 3.

Untreated wood absorbed water during all seven days and it increased by $41.9 \%$.

After a seven-day treatment, water absorption also increased in wood impregnated with polyurethane coating by $27.4 \%$, and in wood impregnated with acrylic by $21.6 \%$. Related to absorption of untreated wood, it was almost twice lower. The water absorption of wood impregnated with polyurethane coating was significantly higher than the absorption of wood impregnated with acrylic coating. The difference was 5.8 $\%$, and it started to be significant on the fourth day, continuing to be significant until the seventh day. The increase of water absorption in wood treated with polyurethane coating can be explained by the presence of polyester component in the coating, which makes it inconsistent with hydrolysis (Daniliuc et al., 2012).

Until the seventh day, water absorption of wood coated with polyurethane coating increased by $11.9 \%$ and of wood coated with acrylic by $12.5 \%$. This is about two times less than water absorption of impregnated wood and about three times less than the untreated wood.

\subsection{Anti-shrinking efficiency - ASE}

3.3. Poboljšanje stabilnosti dimenzija drva

The values of anti-shrinking efficiency of impregnated and coated spruce wood are shown in Figure 4.

The anti-shrinking efficiency of the impregnated wood and coated wood was improved, but during the seven-day immersion it decreased.

The improvement of ASE of wood impregnated with polyurethane and wood impregnated with an acrylic resin is almost equal $(T=0.67)$. On the first day of immersion, ASE improved by $35.7 \%$, and on the second day it decreased to $24.5 \%$. Until the seventh day of immersion, there was no change. On the seventh day of immersion, the ASE of the impregnated wood was $24.2 \%$. The correlation coefficients of the impregnated wood shows $(R=0.26$ and $R=0.34)$ that there was a weak correlative dependence between the percentage of improved ASE and the duration of immersion. The duration of treatment has a negligible impact on ASE, actually a negligible impact on the stability of wood dimensions.

The improvement of ASE of wood coated with acrylic was higher than that of wood coated with polyurethane coatings $(T=3.89)$. However, in a period of six-day immersion, the ASE was equaled. On the first day of immersion, ASE of the coated wood was improved by $74.1 \%$. Then the stability of the coated wood was constantly decreasing and on the fifth day of immersion it was equal with the dimensional stability of the impregnated wood.

In the coated wood, ASE decreased. On the seventh day, it was $17 \%$ and was less than ASE of the

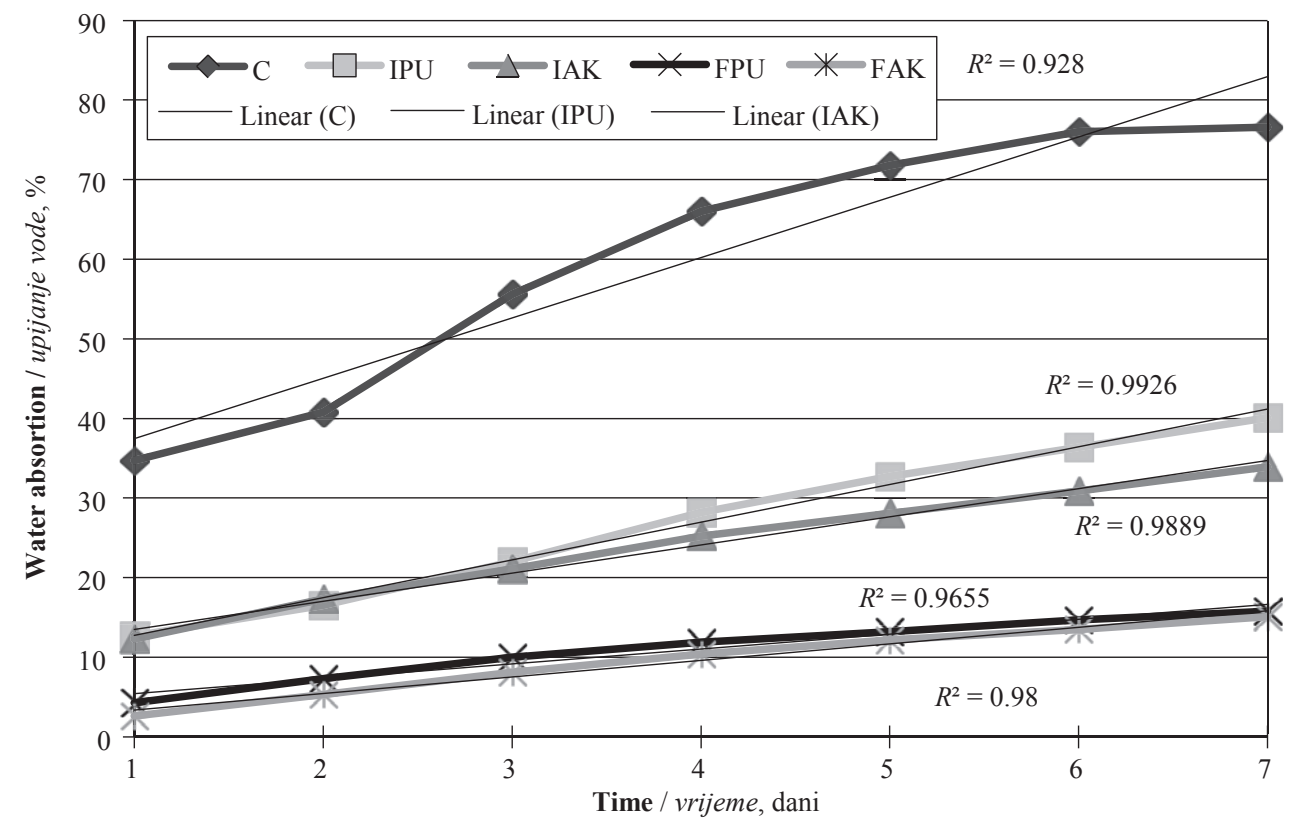

Figure 3 Wood water absorption (C - control samples, IPU - samples impregnated with polyurethane, IAK - samples impregnated with acrylic, FPU - samples coated with polyurethane, FAK - samples coated with acrylic)

Slika 3. Upijanje vode (C - kontrolni uzorci, IPU - uzorci impregnirani poliuretanom, IAK - uzorci impregnirani akrilom, FPU - uzorci s poliuretanskim premazom, FAK - uzorcimi s akrilnim premazom) 


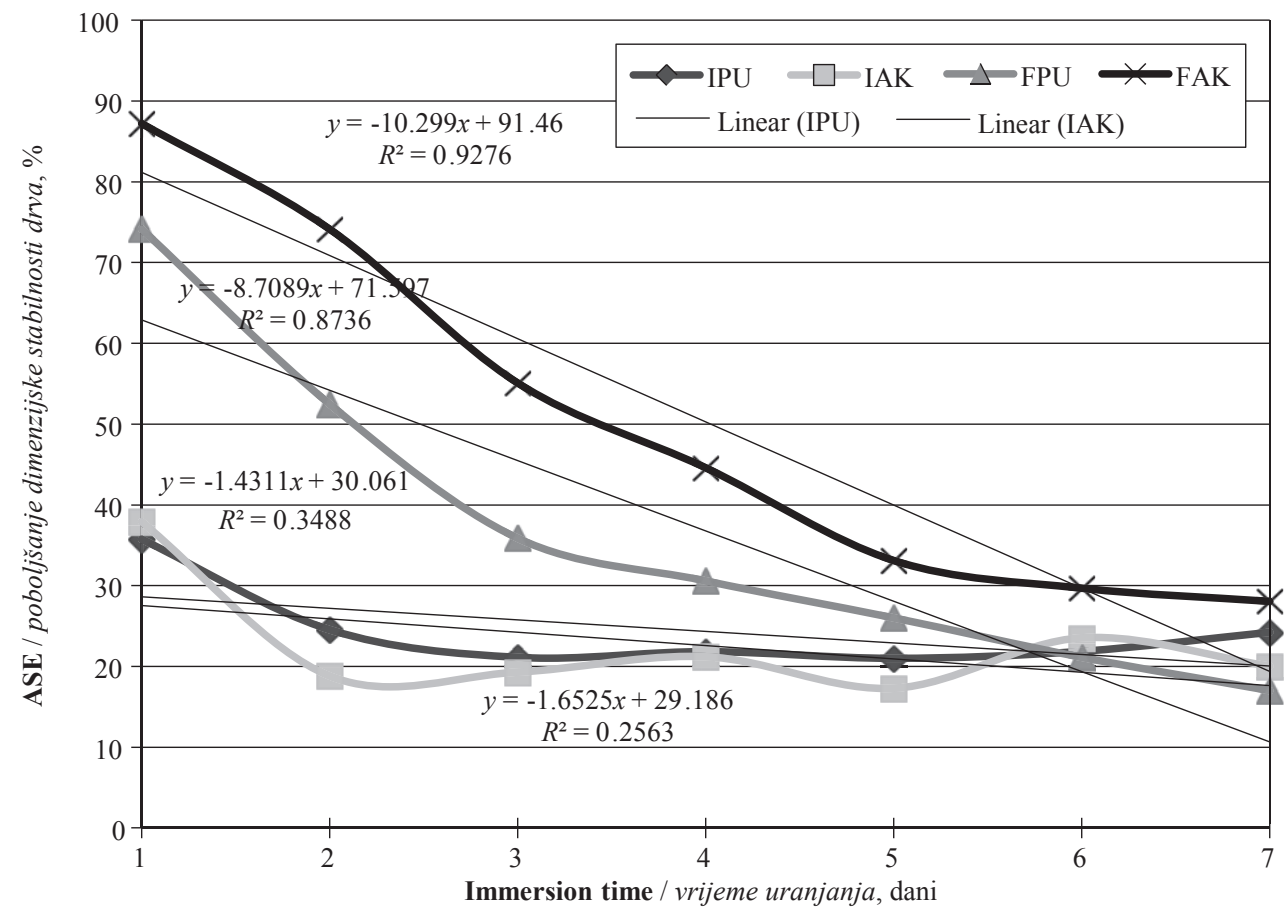

Figure 4 Anti-shrinking efficiency (IPU - samples impregnated with polyurethane, IAK - samples impregnated with acrylic, FPU - samples coated with polyurethane, FAK - samples coated with acrylic)

Slika 4. Poboljšanje stabilnosti dimenzija drva (IPU - uzorci impregnirani poliuretanom, IAK - uzorci impregnirani akrilom, FPU - uzorci s poliuretanskim premazom, FAK - uzorcimi s akrilnim premazom)

impregnated wood $(T=2.76)$. The high correlation coefficient ( $R=0.92$ and $R=0.87$ ) shows that there is a strong correlation dependence between the percentage of improvement in ASE and the duration of immersion of the coated wood, i.e. with the increase of immersion time, the dimensions changed. These ASE results coincide with the literature (Reinprecht, 2010; Hazarika et al., 2014; Can and Sivrikaya, 2016; Giridhar et al., 2017) on wood impregnation with resins.

As well known, when the water leaks through the coated film, the wood starts swelling, causing cracks in the film and weakening the film adhesion. After a few such cycles, parts of the film are removed from the wood surface and the water freely diffuses in, causing unhindered dimensional changes. So, it can be said that the coating is not a proper procedure to stabilize the wood exposed to conditions of increased humidity and action of water.

According to the results obtained from the two applied wood surface treatments, the best wood stability would be certainly achieved by a combination of both treatments. The surface treatment with impregnating modification and film coating on the wood can achieve connection of the surface film with the inner part beneath the surface, where the cellular and intercellular cavities of the wood are filled with the same film material and are able to make a chemical connection with wood.

\section{CONCLUSIONS}

\section{ZAKLJUČCI}

Based on the obtained results of water absorption and dimensional stability of spruce wood impregnated and coated with polyurethane and acrylic coatings, the following can be concluded:

- The water absorption of wood impregnated with polyurethane coating was $27.4 \%$, with acrylic coating $21.6 \%$ and related to untreated wood, it was almost twice lower.

- The water absorption of wood coated with polyurethane coating was $11.9 \%$ and with acrylic coating $12.5 \%$; it was about twice less than that of impregnated wood and about three times less than that of untreated wood.

- The impregnation with polyurethane and acrylic coatings improved the dimensional stability of spruce wood - anti-shrinking efficiency of $24.2 \%$.

- On the first day of immersion, anti-shrinking efficiency of impregnated spruce wood decreased to $32.2 \%$, about 1.5 times less, and till the seventh day it remained unchanged.

- Anti-shrinking efficiency of spruce wood coated with polyurethane and acrylic coatings, constantly decreased during the seven-day period until reaching $77 \%$ or 4.3 times.

- Improvement of dimensional stability - anti-shrinking efficiency of the impregnated spruce wood compared to the coated wood is $29.7 \%$ higher.

- The impregnated spruce wood absorbed water two times less the untreated. It was dimensionally stable. By absorbing water, the coated spruce wood was permanently altering the dimensions.

- This research contributes to the development of a wood treatment method that will improve permeability of surfaces and dimensional stability of the wood immersed or exposed to water. 


\section{REFERENCES}

\section{LITERATURA}

1. Archer, K.; Lebow, S. T., 2006: Wood preservation. Second edition. Primary wood processing principals and practice. Walker J. C. F. (ed.). The Netherlands. Springer. p. 596. https://doi.org/10.1007/1-4020-4393-7_9

2. Bulian, F.; Graystone, J., 2009: Wood Coatings: Theory and Practice. Elsevier Science. United Kingdom.

3. Can, A.; Sivrikaya, H., 2016: Dimensional stabilization of wood treated with tall oil dissolved in different solvents. Maderas, Ciencia y tecnologia, 18 (2): 317-324. https://doi.org/10.4067/S0718-221X2016005000029.

4. Daniliuc, A.; Deppe, B.; Deppe, O.; Friebel, S.; Kruse, D.; Philipp, C., 2012: New trends in wood coatings and fire retardants. European Coatings Journal, 7/8: 20-25.

5. Gindl, M.; Sinn, G.; Stanzl-Tschegg, S. E., 2006: The effects of ultraviolet light exposure on the wetting properties of wood. J. Adhesion Sci. Technol., 20/8: 817-828. https://doi.org/10.1163/156856106777638653.

6. Giridhar, B. N.; Pandey, K. K.; Prasad, B. E.; Bisht, S. S.; Vagdevi, H. M., 2017: Dimensional stabilization of wood by chemical modification using isopropenyl acetate. Maderas, Ciencia y tecnologia, 19 (1): 15-20. https://doi.org/10.4067/S0718-221X2017005000002.

7. Hazarika, A.; Maji, T. K., 2014: Properties of softwood polymer composites impregnated with nanoparticles and melamine formaldehyde furfuryl alcohol copolymer. Plym Eng Sci., 54 (5): 1019-1029. https://doi.org/10.1002/pen.23643.

8. Hill, C., 2006: Wood Modification: Chemical, Thermal and Other Processes. John Wiley and Sons. Ltd. England. 99-127. https://doi.org/10.1002/0470021748.ch5

9. Homan, W. J., 2004: Solid Wood Modification to Improve Wood Qualities. COST Action E18. France.

10. Jirouš-Rajković, V.; Turkulin, H.; Živković, V., 2007: Methods for improving building wood properties. Drvna industrija, 58 (1): 23-33.

11. Mamonova, M., 2000: Morphological characteristic of tracheids in spruce wood from an emission loaded area. Technical University in Zvolen, Slovakia, pp. 119-124.

12. Militz, H., 1993: Enzymatische Behandlungen von Fichtenrund-und Schnittholz zur Verbesserung der Tränkbarkeit. Enzymatic pre-treatment of spruce posts and sawn boards to improve their treatability with wood preservatives. Holz Roh Werkst., 51 (5): 339-346. https://doi.org/10.1007/BF02663806

13. Reinprecht, L., 2011: Possibilities for improvement of moisture and strength properties of decayed spruce wood with natural resins, Wood Research, 56 (3): 285-296.

14. Richardson, B. A., 2003: Wood preservation. $2^{\text {nd }}$ edition, Spon Press. London. 226 p.

15. Rowell, R. M.; Banks, W. B., 1985: Water repellency and dimensional stability of wood. U.S. Department of Agriculture., Forest Service, Forest Products Laboratory. Gen. Tech. Rep. FPL-50. Madison. 13-16.

16. Rowell, R. M.; Youngs, R. L., 1981: Dimensional Stabilization of Wood in Use. U.S. Department of Agriculture, Forest Products Lab., Research Note FPL-0243. Madison. 3.

17. Stamm, A. J., 1964: Wood and Cellulose Science. The Ronald Press Company. New York.

18. Timber Research and Development Association, 1984: Finishes for Exterior Timber. High Wycombe. United Kingdom.

19. Videlov, H., 1980: Zasita i modificirane na drvesinata, Zemizdat, Sofija. 183.

20. *** 1976: ISO 554. Standard atmospheres for conditioning and/or testing - Specifications.

21. *** 1973: ISO 1515. Paints and varnishes - Determination of volatile and non-volatile matter.

22. *** 2011: ISO 2431. Paints and varnishes - Determination of flow time by use of flow cups.

23. *** 1975: ISO 3130. Wood - Determination of moisture content for physical and mechanical tests.

24. *** 1975: ISO 3131. Wood - Determination of density for physical and mechanical tests.

\section{Corresponding address:}

MIHAJLOVSKI NIKOLA, MSc, laboratory technician

Ss. Cyril and Methodius University in Skopje

Faculty of Design and Technologies of furniture and interior - Skopje

16-ta Makedonska brigada 3

1130 Skopje, MACEDONIA

e-mail: mihajlovski@fdtme.ukim.edu.mk 